\title{
FAKTOR-FAKTOR YANG BERPENGARUH TERHADAP \\ PRODUKTIVITAS \\ KERJA KARYAWAN PADA CV. AGRO WISATA DI KOTA PALOPO \\ LANTENG BUSTAMI, ANTONG
}

\begin{abstract}
ABSTRAK
Objek wisata adalah pengelolahan wisata yang memiliki daya tarik dan keindahan yang berwujud peninggalan sejarah seperti wisata petualangan alam, taman rekreasi, dan tempat hiburan.

Sikap mental atau respon untuk membentuk suatu kreaktifitas yang memiliki keberanian dan tidak takut untuk mengeluarkan pendapat sendiri baik benar maupun salah

Pendidikan adalah proses pembelajaran agar mengembangkan potensi pengendalian diri dari kepribadian dan merupakan salah satu faktor yang bertujuan untuk meningkatkan produktivitas perusahaan.

Keterampilan adalah karyawan yang memiliki keahlian atau kreaktifitas, wawasan yang luas dan memiliki kemauan untuk berani menghadapi tantangan baru dan bersedia dan resiko.

Pengalaman adalah kejadian yang pernah dialami, dijalani, dirasai, ditangngungjawabkan baik yang sudah lama maupun yang baru terjadi, pengalaman juga dapat memperbaiki diri sendiri dari kesalahan yang telah di buat selama menjalankan suatu pekerjaan.

$R$ Squared $(R)=0.795$

Artinya bahwa sikap mental, pendidikan, keterampilan, dan pengalaman berpengaruh singnifikasi terhadap peningkatan jumlah pelanggan pada CV. Agro Wisata Kota Palopo yakni sebesar 0.795 atau 79.5\%
\end{abstract}

Kata kunci: produktivitas, kerja karyawan, jumlah pelanggan 


\section{Pendahuluan}

\section{Latar Belakang}

Pariwisata dikembangkan di suatu daerah dengan berbagai alasan, namun biasanya yang menjadi alasan utama adalah untuk menghasilkan manfaat ekonomi dari masuknya defisa bagi daerah dan negara, peningkatan pendapat masyarakat dan pemerintah. Pariwisata juga mendorong proses perlindungan terhadap suatu lingkungan fisik maupun sosial budaya dari masyarakat setempat, karna hal tersebut merupakan asset yang dapat di jual kepada wisatawan dan jika ingin berlanjut maka harus dipertahankan.

Oleh karna itu untuk mengoptimalkan manfaat dan mengurangi berbagai masalah yang di timbulkan dengan adanya pengembangan pariwisata, maka di perlukan perencanaan yang baik dan manajemen pariwisata yang baik pula maka di perlukan perencanaan yang baik dan manajemen yang baik pula. Pengembangan pariwisata nasional mengacu pada landasan idiil (nilai-nilai agama dan pancasila) landasan konstitusional (UUD 1945 dan UU NO. 9 Tahun 1990) yang secara operasional dilaksanakan oleh para pelaku utama pengembangan kepariwisataan.

Seperti diketahui bahwa kota palopo adalah salah satu kota di propinsi Sulawesi selatan yang memiliki potensi atau obyek wisata yang layak dikembangkan di masa kini dan masa akan datang, karna letak kota palopo sangat menunjang akan pengembangan kepariwisataan di propinsi Sulawesi selatan, karena terletak di salah satu jalur wisata yang sudah mulai berkembang. Masalah penelitian ini adalah: faktor-faktor apakah yang berpengaruh terhadap produktivitas kerja karyawan pada CV. Agro Wisata di Kota Palopo?. Tujuan penelitian ini adalah untuk mengetahui faktor-faktor yang berpengaruh dominan terhadap produktivitas kerja karyawan pada CV. Agro Wisata di Kota Palopo.

\section{Metode Penelitian}

Lokasi penelitian

Penulis melakukan penelitian di CV. Agro Wisata kota palopo yang beralamatkan di Jl. A.AHMAD NO. 62 kota palopo. Sedangkan waktu penelitian di lakukan mulai bulan april sampai dengan mei 2012.

Jenis Dan Sumber Data

(a) Data primer yaitu data yang diambil dari sumber asli yaitu pada CV. Agro Wisata kota palopo. Data primer adalah bentuk sikap mental, pendidikan, pengalaman, keterampilan jasa tersebut diperoleh melalui wawancara.

(b)Data sekunder yaitu data yang berupa informasi dari berbagai pihak yang sejalan dengan penelitian ini. Data tersebut dapat diperoleh pada buku bacaan, majalah serta website yang berhubungan dengan judul penelitian. 


\section{Populasi Dan Sampel}

Populasi penelitian adalah pimpinan perusahaan dan karyawan CV. Agro Wisata sebanyak 39 orang karyawan, masyarakat, pelanggan sekaligus sampel penelitian.

\section{Metode Pengumpulan Data}

Untuk memperoleh data sebagai penunjang dalam penulisan penelitian ini maka penulis mengadakan beberapa metode pengumpulan data yaitu (a) Wawancara/Daftar pertanyaan; wawancara adalah teknik pengumpulan data melalui pertanyaan yang di susun secara sistematis yang berisi daftar pertanyaan yang mengacu pada variable penelitian, (b) pengamatan; wawancara yang di maksud di sini adalah teknik untuk mengumpulkan data yang akurat untuk keperluan proses pemecahan masalah tertentu, yang sesuai dengan data, (c) Kepustakaan; kepustakaan digunakan untuk mengumpulkan data merupakan datadata tertuliis yang mengandung keterangan dan penjelasan serta pemikiran tentang fenomena yang masih actual dan sesuai dengan masalah penelitian.

\section{Metode Analisis Data}

Bertitik tolak dari masalah dan hipotesis yang telah dikemukakan sebelumnya, aka dalam pembahasan dan menganalisis permasalahan sekaligus membuktikan hipotesis maka penulis menggunakan metode rekresi berganda linear berganda, untuk mengetahui pengaruh produktifitas kerja karyawan CV. Agro Wisata, dan menurut sulistiyo (2000: 302-303) maka digunakan rumus persamaan rekresi linear berganda sebagai berikut:

$$
\begin{gathered}
\mathrm{Y}=\mathrm{a}+b_{1} X_{1}+b_{2} X_{1}+b_{3} X_{3}+b_{4} X_{4}+\cdots e \\
\text { Dimana } \mathrm{Y}=\text { produktivitas kerja } \\
\quad X_{1}=\text { Sikap Mental } \\
X_{2=} \text { pendidikan } \\
X_{3}=\text { keterambilan } \\
X_{4=} \text { Pengalaman } \\
\mathrm{a}=\text { konstanta } \\
\mathrm{b}=\text { kofisien }
\end{gathered}
$$




\section{Hasil Penelitian}

Analisis Regresi berganda

Tabel 6

Analisis regresi berganda Liner Berganda

\begin{tabular}{|l|l|l|l|l|}
\hline variabel & $\begin{array}{l}\text { Koefisien } \\
\text { Regresi }\end{array}$ & $\begin{array}{l}\text { Standar } \\
\text { Error }\end{array}$ & T huting & Sig \\
\hline X1 & 0.002 & 0.036 & 0.042 & 0.967 \\
X2 & 0.247 & 0.109 & 2.259 & 0.030 \\
\hline X3 & 0.233 & 0.097 & 2.392 & 0.022 \\
\hline X4 & 0.532 & 0.148 & 3.614 & 0.001 \\
\hline
\end{tabular}

Konstanta $=1.867$

$$
\begin{aligned}
R^{2} & =0.795 \\
R^{2} & =0.632 \\
\text { F hitung } & =14.585 \\
\mathrm{~N} & =39
\end{aligned}
$$

Secara matematis hasil dari analisis regresi linier berganda tersebut dapat ditulis tersebut dapat ditulis sebagai berikut :

$$
\mathrm{Y}=1.867+0.002 X_{1}+0.247 X_{2}+0.233 X_{3}+0.534 X_{4}
$$

Persamaan di atas menunjukkan pengaruh masing-masing variable independen $\left(X_{1}, X_{2}, X_{3}\right.$, dan $\left.X_{4}\right)$ terhadap variable dependen $(Y)$.

Uji t (pengujian secara individual )

Untuk menguji pengaruh dari variabel-variabel independen terhadap variabel dependen di gunakan uji t dan uji F. Uji t digunakan untuk menguji koefisien regresi secara individual sedangkan uji $\mathrm{F}$ digunakan untuk menguji koefisien regresi secara simultan.

Untuk membuktikan pengujian apakah secara individual variabel dependen yang mempengaruhi jumlah pelanggan (Y) dengan variabel independen yaitu faktor sikap mental $\left(X_{1}\right)$, pendidikan $\left(X_{2}\right)$, keterampilan $\left(X_{3}\right)$ dan pengalaman $\left(X_{4}\right)$ mempunyai pengaruh terhadap jumlah pelanggan $\mathrm{CV}$. Agro wisata di kota palopo maka, di gunakan uji t. dalam pengujian secara individual (uji t) ini di gunakan taraf signifikasi $(\alpha)=5 \%$ atau 0.05 derajat kebebasan $(\mathrm{df})=(\mathrm{n}-\mathrm{k})=(39-4)=35$ dengan pengujian satu sisi di peroleh $\mathrm{t}$ tabel $=1.690$, adalah kriteria pengujian sebagai berikut:

- Ho diterima jika t hitung $\leq \mathrm{t}$ tabel

- Ho ditolak jika $t$ hitung $\geq \mathrm{t}$ tabel

a. Sikap mental mempengaruhi produktivitas kerja karyawan $\left(X_{1}\right)$ pada $\mathrm{CV}$. Agro wisata kota palopo. 
- Menentukan hipotesis

- Hasil penghitungan komputer di peroleh thitung $=0,042$

- Kesimpulan

Hasil perhitungan komputer menunjukkan nilai $\mathrm{t}$ hitung $>\mathrm{t}$ tabel $(0.042<1.690)$ maka Ho diterima dan Ha ditolak. Dengan diterimanya Ha berarti sikap mental berpengaruh terhadap produktuvitas kerja karyawan CV. Agro wisata di kota palopo.

b. Pendidikan mempengaruhi produktivitas kerja karyawan $\left(X_{2}\right)$ pada CV. Agro wisata di kota palopo. Langkah-langkah pengujian sebagai berikut:

- Menentukan hipotesis

- Hasil perhitungan komputer di peroleh t hitung $=2.259$

- Kesimpulan

Hasil perhitungan komputer menunjukkan nilai $\mathrm{t}$ hitung $>\mathrm{t}$ tabel $(2.259>$ 1.690) maka Ho di tolak dan $\mathrm{Ha}$ di terima. Dengan diterimanya $\mathrm{Ha}$ berarti pendidikan berpengaruh positif terhadap produktifitas kerja karyawan CV. Agro wisata di kota palopo.

c. Keterampilan mempengaruhi produktivitas kerja karyawan $\left(X_{3}\right)$ pada $\mathrm{CV}$. Agro wisata di kota palopo. Langkah-langkah pengujian sebagai berikut:

- Menentukan hipotesis

- Hasil perhitungan komputer diperoleh t hitung $=2.392$

- Kesimpulan

Hasil perhitungan komputer menunjukkan nilai $\mathrm{t}$ hitung $>\mathrm{t}$ tabel $(2.392>$ 1.690) maka Ho ditolak dan $\mathrm{Ha}$ diterima. Dengan diterimanya $\mathrm{Ha}$ berarti keterampilan berpengaruh positif terhadap produktivitas kerja karyawan CV. Agro wisata di kota palopo.

d. Pengalaman mempengaruhi produktivitas kerja karyawan $\left(X_{4}\right)$ pada $\mathrm{CV}$. Agro wisata di kota palopo. Langkah-langkah pengujian sebagai berikut:

- Menentukan hipotesis

- Hasil perhitungan komputer diperoleh t hitung $=3.614$

- Kesimpulan

Hasil perhitungan komputer menunjukkan nilai $\mathrm{t}$ hitung $>\mathrm{t}$ tabel (3.614> 1.690) maka Ho ditolak dan Ha diterima. Dengan diterimanya Ha berarti pengalaman berpengaruh positif terhadap produktivitas kerja karyawan CV. Agro wisata di kota palopo.

Uji f ( pengujian secara simultan)

Untuk membuktikan secara simultan variabel independen faktor sikap mental, pendidikan, keterambilan, dan pengalaman mempunyai pengaruh produktivitas kerja karywan pada CV. Agro Wisata Kota Palopo maka digunakan uji f.

Adapun langkah-langkah penyajiannya sebagai berikut : 
Dengan menggunakan taraf signifikasai $(\alpha)=5 \%$ atau 0.05 derajat kebebasan $(\mathrm{df})=$ $(\mathrm{k}-1) ;(\mathrm{n}-\mathrm{k})=(5-1) ;(39-5) ;=(4)$, maka diperoleh $\mathrm{f}$ tabel sebesar 2.650.

- Kriteria pengujian

- Ho diterima apabila $\mathrm{F}$ hitung $\leq \mathrm{F}$ tabel

- Ho ditolak apabila F hitung $\geq F$ tabel

- Hasil perhitungan komputer diperoleh t hitung $=14.585$

- Kesimpulan

Hasil perhitungan komputer menunjukkan nilai $\mathrm{F}$ hitung $>\mathrm{F}$ tabel $(14.585>$ 2.650 ) maka Ho ditolak dan Ha diterima. Dengan diterimanya Ha berarti sikap mental, pendidikan, keterampilan, dan pengalaman secara bersama-sama berpengaruh positif terhadap produktivitas kerja karywan pada CV. Agro Wisata di kota Palopo.

R Squared $(R)=0.795$

Artinya bahwa sikap mental, pendidikan, keterampilan, dan pengalaman berpengaruh singnifikasi terhadap peningkatan jumlah pelanggan pada CV. Agro Wisata Kota Palopo yakni sebesar 0.795 atau 79.5\%

Determinan

Determinan $r^{2}$ 0,632 atau $63.2 \%$ artinya bahwa sikap mental, pendidikan, keterampilan, dan pengalaman berpengaruh signifikan terhadap naik turunnya produktivitas kerja karywan pada CV. Agro Wisata kota Palopo sebesar 0.632 atau $63.2 \%$ sedangkan sisanya dipengaruhi oleh faktor lain.

\section{Penutup}

Kesimpulan penelitian adalah : (a) Hasil analisis regresi berganda diperoleh persamaan berikut : $\mathrm{Y}=1.867+0.002 X_{1}+0.247 X_{2}+0.233 X_{3}+0.534 X_{4}$. Persamaan tersebut menunjukkan bahwa masing-masing variabel independen (sikap mental, pendidikan, keterampilan, dan pengalaman) mempunyai pengaruh positif terhadap produktivitas kerja karywan CV. Agro Wisata di Kota Palopo. (b) Untuk nilai $X_{1}$. Hasil perhitungan komputer menunjukkan nilai $\mathrm{t}$ hitung $>\mathrm{t}$ tabel $(0.042<1.690)$ maka Ho diterima dan Ha ditolak. Dengan diterimanya Ha berarti sikap mental berpengaruh terhadap produktivitas kerja karywan CV. Agro Wisata Kota Palopo. Adapun saran penelitian ini adalah : (a) Dalam upayah meningkatkan produktivitas kerja karywan pada CV. Agro Wisata di Kota Palopo untuk senantiasa berupayah menerapkan sikap mental, pendidikan, keterampilan dan pengalaman dalam merekrut karywan. (b) Kepada pimpinan CV. Agro Wisata di kota palopo sebaiknya terus meningkatkan kemampuan secara profesional dalam menekuni pekerjaan dan selalu berupaya mencari meningkatkan produktivitas kerja karywan yang baik. (c) Kepada pimpinan CV. Agro Wisata Kota Palopo, penulis berharap agar sistem kerja yang dilaksanakan sekarang dipertambahkan atau lebih tingkatkan. 


\section{Daftar Pustaka}

Anonimus : (http://defenisi pengertian.com/2011/pengertian karywan/) di akses tanggal 21 Februari tahun 2012 : (http: //dansite. Wordprees. Com/2009/04/10/ pengertian tujuan-danmanfaat- penilaian-kinerja-karyawan/) diakses tanggal 21 februari tahun 2012

: (http//defenisi pengertian.com//2012/pengertian pariwisata/) diakses tanggal 17 September tahun 2012

: (http://pengantar pariwisata.com/2012/ilmu pariwisata/) diakses tanggal 17 September 2012

Andi. 2012, mengelolah Data Statistik Hadil Penelitian dengan SPSS 17, wahana komputer, semarang.

Gomes, faustino C. 2003. Manajemen Sumber Daya Manusia, Andi, yogyakarta.

Hunzieker dan krapt, k. 2002. Pengantar Ilmu pariwisata, Aksara, Bandung

Pendit, Nyoman S.2006. Ilmu Pariwisata Sebuah Pengantar Perdana PT. Pradnya paramita, Jakarta.

Pinata, I Gde. 2003. Pengertian pariwisata, Andi, yogyakarta.

Dan Gayatri, Putu G. 2005. Sisiologi pariwisata, Andi, yogyakarta

Priyatno, Duwi 2010. Paham Analisis Statistik Data dengan SPSS, media kom, yogyakarta

Sedarmayanti, 2001. Tata Kerja dan Produktivitas kerja, mandar maju, Bandung

Sinungan, Muchdarsyah.2003. produktivitas, Apa dan Bagaimana, Aksara Bandunng.

Suwantoro,Gamel. 2004. Dasar-Dasar Pariwisata, Andi Yogyakarta.

Sulastiyono, Agus 2008. Manajemen Penyelenggaraan Hotel Seri Manajemen, Usaha Jasa Sarana Pariwisata dan Akomodasi, Alfabeta, Bandung.

Sulastiyono, 2008. Dasar-Dasar Ekonometrika, Yogyakarta.

Yoeti,Oka, A.2002. pengantar Ilmu pariwisat, Bandung . 